\title{
Nitel Araştırma Süreci: Nitel Bir Araştırma Nasıl Yapılır?
}

\author{
Ali BALTACI \\ Mersin Üniversitesi, İslami İlimler Fakültesi, Felsefe ve Din Bilimleri Bölümü, Mersin \\ baltaci7@gmail.com \\ ORCID ID: https://orcid.org/ 0000-0003-2550-8698
}

\begin{tabular}{lr} 
Araştırma Makalesi & DOI: 10.31592/aeusbed.598299 \\
\hline Geliş tarihi: 29.07.2019 & Kevize Tarihi: 27.11.2019 \\
Atıf Bilgisi & \\
Baltacı, A. (2019). Nitel araştırma süreci: Nitel bir araştırma nasıl yapılır?. Ahi Evran Üniversitesi Sosyal Bilimler \\
$\begin{array}{l}\text { Enstitüsü Dergisi, 5(2), 368-388. }\end{array}$
\end{tabular}

ÖZ

$\mathrm{Bu}$ araştırmada, nitel araştırmalarda yaygın olarak kullanılan süreçlerden bahsedilmiş, ayrıca araştırma sürecinin kuramsal temelleri ve uygulamaya yönelik stratejileri ele alınmıştır. Bu çalışma özünde nitel araştırmacıların sıklıkla yöntembilim eksikliklerinden doğan uygulama sorunlarına karşı kavramsal bir zemin oluşturmayı hedeflemiştir. Çalışma ile nitel araştırma sürecinde eksikliği hissedilen kavramsal zemin oluşturulacak ve uygulamaya dönük stratejiler üzerinde durulacaktır. Bu amaçla belirtilen çerçevede alanyazında sıklıkla vurgulanan nitel desenler taranarak, elde edilen veriler kuramsal boyutta tartışılmış, bunun yanında nitel araştırmalara yön verecek yöntemler ve stratejiler hakkında bilgi verilmiştir. Çalışma sonucunda, nitel araştırma sürecinin, nicel araştırmalardan oldukça farklı ve öznel bir süreci ifade ettiği, nitel araştırmaya konu olan sorunsalı tüm dinamikleriyle ve derinlemesine incelemeye çalıştığı belirlenmiştir. Bu çalışma özellikle Türkçe alanyazında eksikliği hissedilen güncel ve kolaylıkla uygulanabilir nitel araştırma yöntemlerindeki eksikliğin tamamlanması amacını gütmektedir. Çalışmanın, nitel araştırma yöntemlerini kullanacak araştırmacılara gerek nitel verilere ilişkin bilgi toplama, araştırma ve gerekse analiz seçimi ve uygulamalarında yol göstereceği umulmaktadır.

Anahtar Kelimeler: Araştırma, nitel araştırma, nitel araştırma süreci, nitel veri toplama, nitel veri analizi.

\section{The Qualitative Research Process: How to Conduct a Qualitative Research?}

\begin{abstract}
In this research, the widely used processes in qualitative research, and the theoretical foundations of the research process and its strategies for implementation are discussed. In essence, this study aims to provide a conceptual basis for the application problems of qualitative researchers, which often arise from methodological deficiencies. With this study, the conceptual ground will be formed which will be lacking in the qualitative research process, and the applied strategies will be emphasized. In this context, the qualitative patterns frequently emphasized in the literature were searched and the data obtained were discussed in the theoretical dimension, and information was given about the methods and strategies that will guide the qualitative researches. As a result of the study, it has been determined that the qualitative research process represents a very different and subjective process than the quantitative research, and the problematic subject to the qualitative research is to examine all the dynamics and in depth. The aim of this study is to complete the deficiencies in the current and easily applicable qualitative research methods, especially in Turkish literature. It is hoped that this study will guide the researchers who will use qualitative research methods in the selection and application of information collection, research, and analysis related to the qualitative data.

Keywords: Research, qualitative research, qualitative research process, qualitative data collection, qualitative data analysis.
\end{abstract}

\section{Giriş}

Bilim tarihine onyedinci yüzyıl sonlarından itibaren egemen olmaya başlayan pozitivist yaklaşımlar, yirminci yüzyıla kadar etkililiklerini sürdürmüş; pozitivizmin gerektirdiği rasyonel ve determinist ilkelerle doğayı ve toplumu anlama çabası, nicel verilere dayalı deneysel incelemelerin değişmez, genellenebilir ve evrensel olduğu yönünde bir kanaat oluşturmuştur. Özellikle yirminci yüzyılın başlarında bilimde yaşanan radikal değişikliklerle beraber nesnel ve indirgemeci anlayış tartışılmaya başlanmıştır. Bu dönemden itibaren bilimin yalnızca nesnel, genellenebilir ve evrensel bilgi üretme süreci olmadığı, bunun yanında öznel bilginin önemini vurgulayan bir anlayış yaygınlaşmıştır.

İnsan, oldukça karmaşık bir fizyolojik sisteme ve bu sistem ile bütünleşik psikolojik süreçlere sahip bir varlık olmasının yanında, sosyal alanda diğer insanlarla iletişimi bakımından sosyolojik bir 
varlıktır. Bu denli karmaşık bir yapıyı salt nicel ve deneysel bulgularla anlamaya çalışmak ya da her insanın genellenebilir ilkeler bütünü olduğunu savunmak sorunlu bir yaklaşımdır. Sürekli değişen duygu, düşünce ve zihin yapısı ile sosyal alandaki dinamik ilişkilere verdiği tepkinin karmaşıklığı dikkate alındığında insanın bütüncül bir yaklaşımla açıklanmasının daha uygun olacağı düşünülmüştür (Merriam ve Grenier, 2019). Cresswell (2002), herhangi bir olgunun açıklanmasında pozitivist ya da tek bir bakış açısının bilim insanını yanılgıya sürüklediğini, buna karşın çoklu bakış açısının işe koşularak daha keskin ölçümler yapılabileceğini bildirmektedir. Söz konusu pozitivist anlayışta insan belirli parçalardan oluşan anlamlı bir bütün olarak tanımlanır ve parçaların incelenmesi ile bütüne ilişkin belirgin bir bilgi sahibi olunabileceği varsayılır (Coffey ve Atkinson, 1996). Örneğin pozitivist akımlardan etkilenen ilk dönem psikoloji çalışmaları, insanı davranışsal yönüyle ele almış ve çoğunlukla deneysel yöntemlerle elde edilen bilgilerin her birey için evrensel ve geçerli olduğunu savunmuştur. Ayrıca ilk dönem psikoloji çalışmalarına yön veren davranışçı ve psikanalist yönelim, insana dair içsel süreçler ile ruh kavramı gibi olguların bilinemeyeceğini iddia etmiş, anılan kavramların pozitif bilimlerin nesnel ölçütleriyle tanımlayamayacağı iddiasından hareketle bilimsel araştırma konusu kapsamında ele almamıştır (Denzin ve Lincoln, 2008b). Zamanla insanın kendine has özellikleri ve çeşitli fenomenler inceleme konusu yapılmış ve bu incelemelerin nicel yöntemin keskin kriterleri ile belirlenemeyeceği görüşü yaygınlık kazanmaya başlamıştır. Bu kapsamda birey ve grup süreçlerine odaklanan daha özellikli araştırmaların yapılmaya başlanması ile ilkin sosyoloji ve psikoloji alanlarında sonrasında sosyal bilimlerin diğer alanlarında niteliğin ön planda tutulduğu araştırma yaklaşımı ön plana gelmeye başlamıştır. Süreç içerisinde nitel araştırma yöntemleri özellikle sosyoloji, psikoloji ve pedagoji gibi bilim alanlarında kullanılmaya başlanmış ve insanın derinlemesine incelenmesine imkân tanıyan yeni ve bütüncül yaklaşımlar gelişmiş, insana dair her olgu ele alınmaya başlanmıştır.

Pozitif bilimlerin genellemeye özgü nicel araştırma yönteminden farklı olarak nitel araştırma, insana özgü bireysel özelliklerin farklı ve derin doğasına odaklanır. Bu kapsamda genellemelerden ziyade bilginin derinliği ve özgünlügünün önemli olduğu iddiasını savunan nitel araştırma, büyük örneklemler yerine daha küçük çalışma gruplarından elde edilen derin ve özellikli verilere odaklanır. $\mathrm{Bu}$ yönü ile nitel araştırma, nicel araştırmanın insanı genellemeler içinde göz ardı edebilen doğasına bir eleştiri de getirmektedir. Sosyal bilimler alanında nicel ve nitel yöntem bir arada kullanılsa da son dönemlerde tek bir araştırma mantığına dayalı yaklaşımın terk edilmeye başlandığı, insana dair olguları açıklamada nitel ve hatta karma (nicel ve nitel araştırmanın bir arada kullanılması) yöntemlerin yaygınlık kazanmaya başladığı söylenebilir. Bu çalışmada nitel araştırmalar hakkında kısa bir bilgi verildikten sonra, bu araştırma yönteminin temel esasları ele alınacak ve nitel araştırma süreci açıklanmaya çalışılacaktır. Bu kapsamda, "nitel bir araştırma nasıl yapılmalıdır?” sorunsalı üzerinden bir nitel araştırmanın nasıl tasarlanması gerektiği, nitel araştırma sürecinde sıklıkla yapılan hatalar ve araştırmacılar için tuzak olabilecek durumlar hakkında öz bilgi sunulacaktır. Nitel araştırma yöntemleri üzerine yazılmış çokça kitap ve makale olsa da literatürde bir nitel araştırmanın yapılış süreçlerini ele alan çalışmaya rastlanılamamış olması bu çalışmanın temel motivasyonunu oluşturmaktadır. Çalışmanın literatürdeki çok sayıda nitel araştırma çalışmasında sıklıkla yapılan hatalara odaklaması ve ideal bir nitel araştırma sürecini ele alması bakımından önemli bir eksikliğin giderilmeye çalışılacağı öngörülmektedir. İlerleyen bölümde nitel araştırma yaklaşımı tartışılacaktır.

\section{Nitel Araştırma Yaklaşımı}

Nitel araştırmaların, yirminci yüzyılın başlarında, insan yaşamının karmaşık doğası, insana dair pozitivist yaklaşımın kabul etmediği olgu ve gizemleri belirleme çalışmaları olarak antropoloji, psikoloji ve sosyoloji bilimlerinde başladığ görülmektedir. Tarihsel olarak nitel araştırmaya, doğal olguları belirleme uğraşından hareketle 'doğal araştırma', probleme ilişkin araştırmacının öznel görüşlerini barındırması sebebiyle 'yorumlayıcı araştırma' ve bir konuyu belirli bir sosyal ortam içinde derinlemesine incelemesinden dolayı 'alan araştırması' gibi farklı isimler verilmiştir (Baltacı, 2017). Nitel araştırma, incelediği probleme ilişkin sorgulayıcı, yorumlayıcı ve problemin doğal ortamındaki biçimini anlama uğraşı içinde olan bir yöntemdir (Guba ve Lincoln, 1994; Klenke, 2016). Bir problemin çözümüne ilişkin gözlem, görüşme ve doküman analizi gibi nitel veri toplama yöntemlerini kullanan nitel araştırma, daha önceden bilinen veya fark edilmemiş problemlerin algılanmasına, probleme ilişkin 
doğal olguların gerçekçi bir şekilde ele alınmasına yönelik öznel-yorumlayıcı bir süreci ifade etmektedir (Seale, 1999).

Sosyal hayatın akışı içindeki olgulara odaklanan ve bu olguları herhangi bir dönüşüme uğratmadan inceleme uğraşı (Maxwell, 2008) içinde olan nitel araştırma, modern sosyal yaşamın çok yönlü ve karmaşı1k doğasını belirlemek için kullanılan çok çeşitli bakış açılarını içerir (Kitzinger, 1995). Sosyal gerçekliğin derinlemesine incelenmesi ve açıklanmasının karmaşıklığı ve giderek farklılaşan problem algısı (Denzin ve Lincoln, 2008b) nitel araştırmanın dinamik yönüne vurgu yapmaktadır. Özellikle etnometodoloji (kültür analizleri), fenomenoloji (olgubilim) ve durum çalışmaları, kuram oluşturma ve eylem araştırmaları gibi çok sayıda yaklaşımı kapsayan nitel araştırmalar, insana dair olgu ve olayların, kendi bağlamından kopmadan ve derinlemesine anlaşılmasını sağlamıştır (Bogdan ve Biklen, 1997). İlerleyen bölümde nitel araştırmanın özelliklerine yer verilecektir.

\section{Nitel Araştırmaların Genel Özellikleri}

Nitel araştırma, insanın kendi potansiyelini anlaması, sırlarını çözmesi ve çabasıyla inşa ettiği sosyal yapı ve sistemlerin derinliklerini keşfetmek için geliştirdiği bilgi üretme biçimlerindendir. Nitel yöntemle desenlenmiş araştırmalarda incelenen olay veya olgu hakkında derin bir algıya ulaşma gayreti söz konusudur (Morgan, 1996). Nitel araştırmalarda genellikle gözlem, görüşme, doküman ve söylev analizi gibi nitel veri toplama tekniklerinin kullanılır. Bunun yanında, insana ilişkin algı ve olayların, sosyal gerçeklikte ve doğal ortamında derinlemesine incelenmesinin esas olduğu nitel araştırma, farklı disiplinleri birleştiren bütüncül bir bakış açısına da sahiptir (Hatch, 2002; Merriam ve Grenier, 2019). Ayrıca nitel araştırmalar, ele aldığı problematiği kendi bağlamında, yorumlayıcı bir yaklaşımla inceler; olay ve olguları yorumlarken insanların onlara atfettiği anlamlara odaklanır. Nitel araştırmaya yönelen bir araştırmacının keşfedici zihinsel süreçleri işlevselleşir (Malterud, 2001) ve olaylar arasındaki farklı bağıntıları daha keskin bir idrak ile algılar (Eysenbach ve Köhler, 2002). Keşfetme süreci, tüm araştırma yöntemlerinde işe koşulsa da nitel araştırmalarda incelenen olay ve olgunun detaylarının keskinleşmesi için elzemdir. Bunun yanında araştırmacı odaklı bir inceleme sürecini içerdiğinden nitel araştırmalar büyük ölçüde özneldir ve araştırmacının kişisel görüşlerinden etkilenebilir (Shenton, 2004; Silverman, 2016).

Nitel araştırmalarda olay ve olgular arasında nedensellik bağı kurulmayabilir (Kuş, 2007; Neuman ve Robson, 2014); ayrıca, olay ve olguların nicel araştırma ile ölçülemeyen nedenleri daha derinlemesine tetkiklerle belirlenebilir (Sandelowski, 1986). Genellikle nicel veriler ve yoğun istatistiklerin göz ardı edilebildiği nitel araştırmalarda, araştırmacının gözlemleri, araştırılan olguya ilişkin metin ve söylev analizi gibi detaylar yer alır (Mallat, 2007). Nitel araştırmalar, olay ve olguların gerçekleşme anına ilişkin derin analizler ve araştırmacının özel betimlemelerini sıklıkla içerirler (Golafshani, 2003). Araştırmacı, olay ve olguların gerçekliğini bozmadan sunmakla yükümlüdür; olay ve olgular kendi gerçekliklerinden ya da bağlamından koparılmaz ve oluştukları halleri ile muhafaza edilmeye çalışılır (Miles ve Huberman, 1994). Araştırmacı, olay ve olguları kendi bağlamında analiz etmeye, yorumlamaya ve anlamlandırmaya çaba gösterir.

Nitel araştırmacılar, genellikle üç tip veri seti üzerinde çalışırlar:

1) Doğa ve çevreyi konu edinen veri setleri (araştırmanın yapıldığ 1 evren, doğal çevre, sosyal yaşantı gibi demografik veya fiziki özellikler) (Strauss ve Corbin, 1990),

2) Araştırma sürecine vurgu yapan veri setleri (araştırma sürecinde veya öncesinde yaşanan olay ve olgular) (Patton, 1990),

3) Araştırılan olay ve olgunun algılanma biçimine vurgu yapan veri setleri (araştırma sürecinde gerek araştırmacı gerekse araştırılan olay ve olgulardaki içsel değişiklikler, çatışmalar veya diğer psikosomatik tepkiler vb.) (Morgan ve Smircich, 1980).

Söz konusu üç veri setini elde etmek isteyen araştırmac1, görüşme, gözlem ve söylev/metin analizi gibi yöntem ve teknikleri kullanabilir. Görüşme, nitel araştırmada çoğunlukla kullanılan bir teknik olarak öne çıkmaktadır. İnsanların olay ve olgular hakkındaki görüşleri, kendi tecrübeleri, duygusal birikimleri ile alg1 ve değerlerinin belirlenmeye çalışıldığı durumlarda başvurulan görüşme 
yöntemi, detaylı bilgi sağlaması ve uygulama kolaylığı açısından tercih edilmektedir (Fossey, Harvey, McDermott, ve Davidson, 2002; Hay, 2000; Seidman, 2006). Görüşmelerin, farklı nitel yöntem ve tekniklerle zenginleştirilmesi araştırmanın güvenirliğini artırır (Marshall, 1996); ayrıca, farklı bakış açılarına yer veren ve farklı detayları destekleyen araştırmacı gözlemleri ile metin analizleri de araştırmanın geçerliğini artıracaktır (Baxter ve Jack, 2008).

Nitel araştırmaların tasarlanması ve yürütülmesi sürecinde araştırmacılar, esnek ve dinamik bir çalışma alanına sahip olurlar. Araştırma sürecinin her basamağında araştırmacıların yeni yöntem ve yaklaşımlar geliştirebilmesi ve araştırmanın etkisini arttıracak yeni düzenlemeler yapabilmesi olarak ifade edilen esneklik, nitel araştırmanın araştırmacıya sunduğu temel özelliklerindendir (Guba ve Lincoln, 1994; Merriam, 1998; Patton, 1990). Araştırmacının yeni bilgilere erişimine olanak sağlayan esneklik, keşfedici bir yaklaşıma da izin verir. Keşfedici yaklaşım nitel araştırma içinde sıklıkla başvurulan ve araştırma verilerinin yeni verilerle çeşitlendirilip detaylandırılmasını sağlayan önemli bir nitelik olmasının yanında, özellikle veri toplamanın görece zor olduğu veya az çalışılmış konuların incelenmesinde kullanışlı bir yaklaşımdır (Bengtsson, 2016; Coffey ve Atkinson, 1996; Denzin ve Lincoln, 2008a).

Nicel araştırmalar, katılımcılardan belirli ölçme araçlarıyla elde edilen verilerin çeşitli istatistik analizleri kullanılarak genellenebilir ve evrensel bilgiye dönüştürülme süreci iken (Baltac1, 2018; Crabtree ve Miller, 1999); nitel araştırma bilginin genellenmesinden veya evrensel boyutundan ziyade, bilginin detayları ve derinliği ile incelenen olguyu en iyi şekilde ifade etmesini konu edinir (Connelly, 2016; Marshall ve Rossman, 2014; Şimşek ve Yıldırım, 2011). Objektif ve doğrudan ölçülebilir davranış ve tutumlarla daha az ilgilenen nitel araştırmalar, inceledikleri olay ve olguların arkasındaki içsel (duygusal) ve kavramsal yapılarla ilgilenir (Makatouni, 2002). Bunun yanında, karma desen araştırma olarak bilinen ve her iki araştırma deseninin (nicel araştırma ile beraber yürütülen nitel araştırmalar) güçlü yönlerini birleştiren araştırma yönteminde nitel yaklaşımlar, nicel verilere duygu, derinlik ve farklı bakış açıları ekleyebilir. Bu sayede nicel verinin inandırıcılığ 1 ve etkisi de artar (Creswell, 2002; Merriam, 1998; Patton, 1990).

Nicel araştırmaların kanıt arayıcı kimliği ve büyük örneklem grupları üzerinde çalışmayı gerektiren doğasına karşın, nitel araştırmalar az örneklem veya küçük çalışma grupları ile yürütülür (Baltac1, 2018; Marshall, 1996; Teddlie ve Yu, 2007). Örneklemin düşük sayıda tutulması, araştırmacıya belirli örneklemlerle detaylı ve derinlemesine inceleme imkânı sağlarken, zaman ve maliyet olarak yürütülebilir bir araştırma yapmasını kolaylaştırır (Kvale, 1994; Pope, Ziebland, ve Mays, 2006). Ayrıca nitel verilerin analizinde araştırmacı öznel duygu ve düşünceleri ile yorumlayıcı ve eleştirel bir yaklaşımla kendi deneyimlerini işe koşarken, nicel araştırmaların analizi çoğunlukla araştırmacının duygu ve düşüncelerinden uzak, tanılayıcı ve genellenebilirdir (Sandelowski, 1986). İlerleyen bölümde nitel araştırma süreci veya nitel araştırmacıların çoğunlukla izlediği temel aşamalar tanıtılacaktır.

\section{Nitel Araştırma Süreci}

Her araştırmada olduğu gibi nitel araştırmalarda da öncelikle araştırılacak konuya ilişkin bir farkındalık ve merak duygusu olmalıdır. Problemi tanıma, problemin farkında olma ve problemin çözümüne ilişkin merak duyma önemlidir. Çünkü araştırma süreci içinde araştırmacı, kolaylıkla dağılabilmekte ve sıkılabilmektedir (Creswell, 2002; Guba ve Lincoln, 1994; Shenton, 2004). Problemin analiz edilerek detaylarının belirlenmesi, çözüme ilişkin alternatif yaklaşımlar arasından hangisinin problemi tutarlı şekilde çözeceğini seçmek için önemlidir (Morgan ve Smircich, 1980; Morse, 2016). Ardından çalışma tasarlanır ve veri toplama aracı geliştirilir. Veri toplama süreci uzun sürebilir ve araştırmacı ilgili ilgisiz tüm nitel verileri edinmiş olabilir (Neuman ve Robson, 2014). Bu noktada verilerin sınıflandırılması gereklidir. Sınıflandırma ile veriler daha etkili bir şekilde analiz edilerek yorumlanır (Bogdan ve Biklen, 1997). Araştırmanın son aşaması olan raporlaştırma, farklı problemleri görünür kılabilir. Çünkü nitel araştırmanın amaçlarından biri de belirli problemlerin çözülmesi ve yeni problem durumlarının fark edilmelerinin kolaylaştırılmasıdır (Mallat, 2007; Pope vd., 2006). Bu döngü tüm araştırma süreci boyunca devam eder. Nitel araştırma sürecini Şekil 1'deki gibi görselleştirmek mümkündür. 


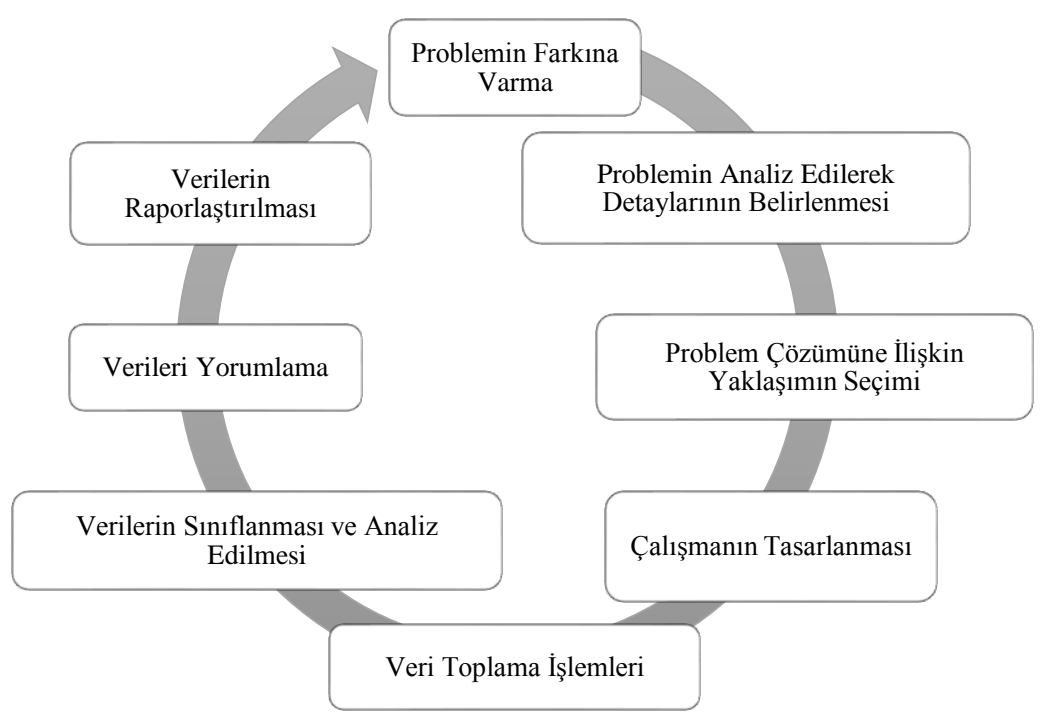

Şekil 1. Nitel Araştırma Süreci, Kaynak: (Creswell, J. W. (2002). Educational research: Planning, conducting, and evaluating quantitative. Prentice Hall Upper Saddle River, NJ. ; Patton, M. Q. (1990). Qualitative evaluation and research methods. SAGE Publications, inc.)

Şekil 1'de gözlemlenen süreç kendi içinde belirli durumları da içerir. Nitel araştırma süreci başladıktan sonra araştırmacının dikkate alması gereken üç önemli durum vardır. Öncelikle araştırmaya esas teşkil edecek ve araştırma konusunu tanımlayacak detaylı bir kuramsal çerçeve oluşturulmalıdır. Ardından araştırmacı sistematik, uygulanabilir, zaman ve diğer imkânlar yönünden esnek bir araştırma stratejisi geliştirir. Son olarak araştırmaların belirli bir okuyucu kitlesini hedeflediği unutulmamalı; araştırma, okuyucunun idrak edebileceği açık ve anlaşılır bir dil ile kendi içinde tutarlı bir şekilde raporlaştırılmalıdır (Bengtsson, 2016; Connelly, 2016; Creswell, 2002; Golafshani, 2003; Kitzinger, 1995; Merriam ve Grenier, 2019; Miles ve Huberman, 1994; Morgan, 1996). İlerleyen bölümde nitel araştırma sürecinin unsurları ele alınacaktır.

\section{Araştırma Probleminin Belirlenmesi}

Araştırma problemi, araştırmacının somut olarak farkına vardığ 1 ve uygulamada yaşanan bu sorunun çözümlenmesini gerekli gördüğü bir olgu veya olay olabilir. Bunun yanında belirli bir literatür taraması yapılarak veya araştırmacının geçmiş deneyimlerinden hareketle de sorun tespit edilebilir (Sandelowski, 1986). Araştırma problemi belirlenirken problemin önemi, çözümlenebilme durumu ve araştırmacının imkânları da göz önünde bulundurulmalıdır (Patton, 1990). Problemler çoğunlukla genel ifadeler şeklinde oluşturulur ve sınırlarının belirlenmesi amacıyla belirgin bir literatür taramasının yapılmasını gerektirir. Literatür taraması, hem araştırmacı için problemin sınırlarının belirlenmesini sağlar hem de problemin diğer aşamaları için kuramsal anlam zemini oluşturur (Creswell, 2002; Shenton, 2004; Strauss ve Corbin, 1990).

\section{Kuramsal Çerçevenin Hazırlanması}

Araştırma problemi belirlendikten sonra araştırmacı, probleme ilişkin daha önce yapılmış çalışmaları, problem alanını çevreleyen literatürü ve literatürde yer alan gelecek projeksiyonlarını inceler. Gelecek projeksiyonları, araştırmaların genellikle sonuç bölümünde yer alan ve araştırma kapsamında elde edilen sonuçları daha anlamlı kılacak ve diğer araştırmalara yön verecek önerilerdir. $\mathrm{Bu}$ öneriler, probleme ilişkin yapısal ve uygulanabilir yönlendirmeler içerirler (Denzin ve Lincoln, 2008a; Kitzinger, 1995; Şimşek ve Yıldırım, 2011). Araştırmacı odaklandığı probleme ilişskin kuramsal çerçeveyi hazırlarken mutlaka diğer araştırmalarda eksik kalan noktaları da ele almalıdır. Kuramsal çerçevenin hazırlanması, problemle ilgili sınırların belirlenmesi, problemin boyutlarının tanımlanması ve problem durumu ile ilişkili farklı olguların belirlenmesi işlemlerinde önem arz eder (Kvale, 1994). Ayrıca veri toplama süreci sonunda, toplanan verilerin analiz edilmesi aşamasında kullanılacak kategori ve temaların seçiminde kuramsal çerçeveden yararlanılır. Araştırmanın amacına uygun yürütülmesi, 
konuya ilişkin terim ve kavramların doğru anlaşılması ile mümkün olacağından ilgili literatür eksiksiz taranmalı ve araştırma sürecine yön veren bir esneklikte kurgulanmalıdır (Baxter ve Jack, 2008; Creswell, 2002; Guba ve Lincoln, 1994; Merriam ve Grenier, 2019; Miles ve Huberman, 1994).

\section{Araştırma Sorularının Hazırlanması}

Nicel araştırmalarda hipotezlere dayalı bir yönelim, nitel araştırmalarda ise incelenen olay veya olguya ilişkin problem durumunun soru cümlesine dönüştürülmesi söz konusudur. Kuramsal çerçeve ile sınırları belirlenen problem durumu, belirli bir soru formunda biçimlendirilir; araştırma sorusu, kuramsal çerçevenin de yönelimini belirler ve dağınık bir literatüre ilişkin net bir görüş alanı oluşturulmasını sağlar (Patton, 1990; Sandelowski, 1986). Yani araştırmacı karmaşık bir konuyu çalışsa da yazacağı belirgin araştırma sorusu ile bu karmaşayı önleyecek bir kuramsal alan oluşturur. Bu açıdan araştırma sorularının belirlenmesi ile kuramsal çerçevenin oluşturulması çoğu nitel araştırmada eş zamanlı ilerleyen ve birbirlerini etkileyen süreçlerdir (Şimşek ve Yıldırım, 2011).

\section{Çalışma Grubunun (Evren ve Örneklem) Belirlenmesi}

Örnekleme, belirli bir evrenin tümünden bilgi toplanmasına imkân olmadığı durumlarda kullanılır. Nicel araştırmanın genellemeye dayalı ve çoğunluk vurgulu örneklem yöntemlerinden ziyade nitel araştırmalar, belirli bir örneklemin detaylarına odaklanır. Nitel araştırmada farklı örnekleme biçimleri bulunsa da genellikle araştırılan konunun en iyi şekilde açıklanmasına olanak tanıyacak ve araştırma probleminin çözümüne en iyi katkıyı sunacak örneklere ulaşılmaya çalışılır (Baltacı, 2018). Örneklem seçiminde araştırmacı, veri topladığı alanı tanımalıdır. Genellikle küçük gruplarla ve az örneklemlerle yürütülen nitel araştırmalar, veri kalitesini arttırmak için belirli zamanlarda aynı örneklem grubu üzerinde tekrarlanarak daha fazla detaya erişim sağlanabilir (Neuman ve Robson, 2014). Bunun yanında örneklem seçiminde etkili olan diğer bir faktör, araştırmacının sahip olduğu kaynakların sınırlılığıdır. Zaman ve maddi imkânlardan yoksun olan bir araştırmacının, yıllar sürecek nitel çalışmaları yürütmesi mümkün görünmediğinden farklı örnekler ve imkânları kullanarak problemi çözmesi söz konusudur (Creswell, 2002; Makatouni, 2002; Mallat, 2007; Marshall, 1996).

Nicel araştırmanın genellemelere dayalı doğası, evreni temsil edecek büyük ve geniş örneklemlere ihtiyaç duymasını gerektirir. Oysa nitel araştırmalar, çoğunlukla gözlem ve görüşmelere dayalı olarak yürütüldüğünden büyük ve geniş örneklemlere ihtiyaç duymaz; çünkü belirli bir aşamadan sonra gerek gözlemler gerek görüşmeler kendini tekrar etmeye başlayacaktır (Morse, 2016; Shenton, 2004). Araştırmacı tekrarlarla karşılaştığında verilerin doygunluğa ulaştığını farketmeli, verileri çeşitlendirmektense detaylandırması gerektiğini anlamalıdır. Bu durumda ya araştırma sorularına yeni sorular ekleyerek veri çeşitliliğini sağlamalı veya görüşmelerin derinliğine inmek için topladığı verilerden farklı anlamlar üretmeye çalışmalıdır (Silverman, 2016). Büyük ve geniş örneklemler üzerinde çalışmak araştırmacı için yoğun bir zaman, emek ve diğer kaynaklarda maliyet oluşturur; ayrıca örnekleme ulaşmak her durumda kolay değildir (Kvale, 1994). Örneğin madde bağımlıları veya suça karışmış kişiler gibi zor ulaşılan örneklemler ile araştırma yapan bir araştırmacı çoğu kez tek seferde görüşme yapmak zorunda kalabilir, kısıtlı sürede görüşmeyi detaylandırmak ya örneklemi iyi tanımakla ya da araştırmanın kuramsal çerçevesine hâkim olmakla sağlanabilir. Bu sebeple sınırlı zaman ve imkânlara sahip olan araştırmacı, genelleme kaygısı gözetmeksizin olabildiğince evreni temsil etmeye çalışır.

Örnekleme olarak adlandırılan evreni temsil etme durumu, her bir örnek için evrenin çeşitliliğini, zenginliğini, farklılığını ve aykırılığını yansıtan bir genişliğe sahip olmalıdır. Genellikle nitel araştırmalarda olasılığa dayanmayan amaçlı örnekleme yöntemleri ilgi görse de örneklem seçiminde, evreni temsil etme derecesinden ziyade araştırma konusuna uygunluk da önemlidir (Baltacı, 2018; Sandelowski, 1986). Olasıllk temelli örnekleme, evreni temsil edecek geçerlik ve büyüklükte örneklem seçilmesi ve bu örneklemin araştırma konusunda veri toplamaya elverişli olması gerekliliği aranır. Olasılıklı örnekleme, genelleme yapmaya daha yatkın bir imkân sunarken; amaçlı örnekleme, zengin bilgi içerdiği düşünülen durumların detaylı incelenmesini kolaylaştırır (Denzin ve Lincoln, 2008a; Guba ve Lincoln, 1994; Morgan ve Smircich, 1980). 
Nitel araştırmalarda: aykırı veya anormal durum örneklemesi, yoğunluk örneklemesi, maksimum çeşitlilik örneklemesi, benzeşik (homojen) örneklem, tipik durum örneklemesi, kritik durum örneklemesi, kartopu veya zincir örnekleme, kuram tabanlı örnekleme, doğrulayıcı veya yanlışlayıcı durum örneklemesi, tabakalı amaçlı örneklem, firsatçı veya beliren örneklem, amaçlı rasgele örnekleme, siyasi veya politik durum örneklemesi, kolay ulaşlabilir veya elverişli örneklem, hibrit veya karma örneklem gibi farklı örnekleme yöntemleri kullanılabilir (Baltacı, 2018; Creswell, 2002; Hatch, 2002; Hay, 2000; Klenke, 2016; Kuş, 2007; Malterud, 2001; Marshall, 1996; Merriam, 1998; Merriam ve Grenier, 2019; Şimşek ve Yıldırım, 2011; Teddlie ve Yu, 2007).

\section{Veri Toplama Araçlarının Geliştirilmesi}

Nitel araştırmalarda genellikle gözlem, yapılandırılmış veya yarı yapılandırılmış görüşme, odak grup görüşmesi, söylev ve metin analizi gibi veri toplama yöntemleri kullanılmaktadır. Bununla birlikte sinema filmi, çeşitli afişler, sanat eserleri, medya yayınları (radyo veya televizyon programları) ve sosyal medya kaynakları (bloglar, sosyal medya hesapları ve anlık mesaj panolar vb.) da veri toplama aracı olarak kullanılabilmektedir (Forrester ve Sullivan, 2018). Araştırmacı çoğu durumda farklı yöntemleri birlikte kullanarak verilerin geçerliğini ve güvenirliğini arttırma yoluna gider. Ayrıca örneklem özelliklerine göre farklı veri toplama araçlarına yer verilebilir (Eysenbach ve Köhler, 2002; Kvale, 1994; Patton, 1990; Seidman, 2006). Örneğin politikacıların seçim döneminde vadettiklerinin seçimlerden sonra gerçekleştirilme durumunu konu edinen bir çalışmada, seçmenlere yönelik bir görüşme formu ile seçim sonrası yapılan işlere yönelik gözlemler kullanılabilir.

Araştırmacı, veri toplama araçlarını geliştirirken olabildiğince esnek olmalı, araştırmanın çözümüne katk1 sağlamayacak ve kendisine zaman kaybettirecek ayrıntılara odaklanmaktan kaçınmalıdır. Veri toplamada 'zaman tuzakları' olarak adlandırılan bu durum, çok sayıda ve çeşitli veri setlerine erişen araştırmacıların sıklıkla yaptıkları bir hatadır (Denzin ve Lincoln, 2008a; Merriam ve Grenier, 2019; Miles ve Huberman, 1994; Shenton, 2004). Yapılandırılmış ve yarı-yapılandırılmış görüşme formlarının belirli ve az sayıda soru içermesi; gözlemler için önceden belirlenmiş davranış çizelgeleri geliştirilmesi; metin ve söylev analizi için hangi ölçütlerin nasıl ele alınması gerektiğini gösteren bilgi botları hazırlanması önemlidir (Eysenbach ve Köhler, 2002; Seidman, 2006).

\section{Verilerin Toplanması}

Araştırmacı, çalışma grubunu belirledikten ve veri toplama araçlarını geliştirdikten sonra alana yönelir ve verileri toplamaya başlar. Bu aşama araştırmacı için oldukça uzun ve zahmetli olabilecek bir süreci beraberinde getirir. Eğer araştırmacı, probleme ilişkin yeterli kuramsal inceleme yapmadıysa veya uygun örneklem ile veri toplama araçlarını geliştirmediyse ya sürecin içinde takılıp kalır ve bir süre sonra kısa yoldan problemi çözmeye yönelik uğraşlar içine girer veya araştırmadan vazgeçer (Creswell, 2002; Patton, 1990; Silverman, 2016). Veri toplama aşaması, araştırmacı için gerçeklikle yüzleşme anıdır. Nitel araştırmalarda genellikle görüşme, gözlem ve doküman inceleme olmak üzere üç veri toplama tekniği kullanılmaktadır.

\section{Görüşme}

Araştırma örnekleminde yer alanların, araştırma konusu hakkında bilgi, duygu ve düşüncelerini aktif olarak açıkladığı, yaşam öyküsünü anlattığı veri toplama tekniği, görüşme olarak adlandırılır. Görüşmenin amacı, katılımcıların iç dünyalarına erişerek onların özgün bakış açılarının belirlenmesidir. Görüşme, araştırılan konu hakkında bireyin yaşanmışlıkları, farklı deneyimleri, tutumları, düşünceleri, niyetleri, yorumları, zihinsel algıları ve tepkileri gibi gözlenemeyen bilgilere ulaşılmasına olanak sağlar (Bengtsson, 2016; Seidman, 2006).

Yapılandırılmış, yarı yapılandırılmış, yapılandırılmamış ve odak grup görüşmesi şeklinde farklı görüşme teknikleri vardır (Marshall, 1996). Ne şekilde yapılırsa yapılsın araştırmacının iyi bir görüşme yapabilmesi için araştırdığ konunun kuramsal çerçevesini iyi bilmesi ve görüşme öncesi iyi bir şekilde 
hazırlanması gereklidir. Görüşme öncesi hazırlık büyük ölçüde araştırmacının zihinsel ve duygusal olarak hazırlanmasını gerektirse de görüşme formu hazırlanması da önemlidir (Marshall ve Rossman, 2014). Görüşme formu hazırlanırken dikkate alınması gereken ilkeler aşă̆ıdaki gibi sıralanabilir:

- Cevaplayıcı tarafından kolaylıkla anlaşılabilir sorular yazılmalıdır,

- Araştırılan konunun detaylarını belirleyebilecek ve konuyu derinleştirecek sorular hazırlanmalıdır,

- Cevaplama süresini uzatan ve konuyu genel hatları ile ele açık uçlu ve özellikli olmayan sorulardan kaçınılmalıdır,

- Katılımcıyı araştırma dışına yönlendirebilen belirsiz sorulardan kaçınılmalıdır,

- İncelenen konunun farklı özelliklerini açığa çıkarabilecek, konuyu farklı ve nitelikli kılabilecek çok boyutlu sorular hazırlanmalıdır,

- Katılımcinın incelenen konudan sapması veya yeterli düzeyde bilgi vermemesi durumunda katılımcıyı incelenen konuya sevk edecek ve konunun farklı detaylarına erişilmesini sağlayacak alternatif sorular hazırlanmalıdır,

- Katılımcılarla farklı zamanlarda yapılacak görüşmeler için bir önceki görüşmede sorulan sorulardan farklı nitelikte ve incelenen konunun daha iyi anlaşılmadını sağlayacak türden sorular hazırlanmalıdır,

- İncelenen konuyla ilgili katılımcılara sorulacak tüm soruların belirli bir mantıksal düzeni olmalıdır,

- Birbiri üzerine inşa edilmiş sorularla katılımcıların belirli bir mantık çerçevesinde kalması ve incelenen konunun farklı yönlerinin sürekli detaylandırılması ve geliştirilmesi sağlanmalıdır (Eysenbach ve Köhler, 2002; Forrester ve Sullivan, 2018; Kvale, 1994; Seidman, 2006).

Nitel araştırmalarda kullanılan soru tipleri çeşitlilik arz etmektedir. Aşağıda nitel araştırmada kullanılan temel soru tipleri yer almaktadır:

1. Tanıtıcı Sorular: Bu tip sorular katılımcının herhangi bir etkileme olmaksızın, kendiliğinden kendisi ve hayatı hakkında geniş cevaplar vermesine olanak sağlayan sorulardır (Denzin ve Lincoln, 2008b)

2. Takip soruları: $\mathrm{Bu}$ tip sorular, elde edilen verilerin çeşitliliğini sağlamak amacıyla belirli bir mantıksal zeminde siralanan sorulardır (Forrester ve Sullivan, 2018)

3. Sondaj Soruları: Burada görüşmeci verilen cevabın peşine düşer ve daha derinlemesine bilgi edinmeye çalışır. Odaklanılan konu hakkında tekrarlı sorular yöneltilerek detaylara erişmeye çalışır. Bu tip sorular takip sorularına benzese de mantıksal bir sıralama olmaksızın tamamen içgüdüsel olarak incelenen konuya sondaj yapılabilir (Kvale, 1994)

4. Özelleştirici Sorular: Görüşmeci bazen bir konuyu en ince ayrıntısına kadar öğrenmek isteyebilir. Hatta bu nicel veriler dahi olabilir. Özelleştirici soru, incelenen konunun bir yönüne odaklanarak sadece o konu hakkında sorulan sorulardır. Özelleştirici sorular, takip ve sondaj soruları kadar detay içermeyebilir. Çoğunlukla veriler doygunluğa ulaştı̆̆ında ve veri çeşitlemesi yapıldığı aşamada kullanılmaktadır (Marshall ve Rossman, 2014).

5. Doğrudan Sorular: Bu tip sorular genellikle evet/hayır ya da kısa cevaplar üreten sorulardır. Bu tip sorular katılımcinın kendini uzun uzun ifade etmesinden sonra belli bir durumu onaylayıp onaylamadığı, ya da eksik kaldığını düşünülen, anlaşılmayan bir noktayı onaylamak için sorulabilecek sorulardır (Crabtree ve Miller, 1999).

6. Dolaylı Sorular: Burada genellikle katılımcının yansıtma tekniği ile cevap verebileceği sorular sorulur. Kapalı nitelikte veya metaforik/sembolik bir dil kullanılarak sorulan ve çoğu durumda doğrudan sorulması mümkün olamayabilecek veya özel bir jargon olarak algılanabilecek konuları incelerken dolaylı sorular kullanılabilir (Antwi ve Hamza, 2015).

7. Yapılandırıcı Sorular: Görüşmeci görüşme sürecinden ve bir konunun ne zaman kapatılması gerektiğinden sorumludur. Görüşülen kişi eğer kendini tekrar etmeye başlamışsa orada araya girerek "özür dilerim size yeni bir konu hakkında sorular sormak istiyorum" diyerek müdahalede bulunmalıdır. Yapılandırmacı sorular, görüşmeyi tehlikeye uğratabilecek durumlarda başvurulan ve görüşmeyi yapılış amacına yönlendiren sorulardır (Bengtsson, 2016).

8. Sessizlik: Sessiz kalmak kimi zaman bir soru anlamına gelebilir. Katılımcıya sık sık sorduğunuz sorular üzerinde (Özellikle geçmişe ait ise) düşünmesine firsat vermek için beklenedilir. Bu durum, katılımcının açıklamasını istenilen bir soru gibi algılanabilir (Merriam, 1998). 
9. Yorumlayıcı Sorular: Görüşme esnasında yorumlama, katılımcının söylediklerini görüşmecinin kendi cümleleriyle yeniden ifade etmesidirr. Katılımcının söylediklerinin ona geri yansıtılması hem ona düşünmesi için zaman verecek hem de ne söylediğini görüşmecinin nasıl anladığını ortaya koyacaktır. Aynı zamanda katılımcı görüşmecinin onu dinlediğinden de emin olacaktır (Baxter ve Jack, 2008).

Özellikle görüşme sürecinde soruların açık ve anlaşılır bir şekilde katılımcıya yöneltilmesi ve gerekli durumlarda ek sorularla araştırılan konunun derinleştirilmesi sağlanmalıdır. $\mathrm{Bu}$ noktada araştırmacıların çok sayıda katılımcıya ulaşma çabası, sıklıkla yapılan bir hatadır (Creswell, 2002; Makatouni, 2002). Görüşmelerde sayıdan ziyade nitelik önemlidir ve tek bir katılımcıdan bile araştırmanın probleminin çözümü için gerekli veri sağlanabilir. Ayrıca katılımcıları aynı anlama gelen veya daha önceden farklı şekillerle sorulan sorularla sıkmak, yinelenen kavramlar veya anlatım bozukluğu olan sorular yöneltmek, katılımcı görüşlerini kaydetmemek ve bu görüşlerle dalga geçmek veya gülmek de toplanan verilerin kalitesini düşürecektir (Merriam, 1998; Patton, 1990; Teddlie ve Yu, 2007).

\section{Gözlem}

Herhangi bir ortamda veya düzenlenmiş mekânlarda katılımcıların tutum ve davranışlarını gözlemlemek veya araştırılan konunun biçimsel boyutunu tanımak amacıyla kullanılan bir yöntemdir. Eğer araştırmacı herhangi bir ortamda veya kendi düzenlediği mekânda oluşan bir davranışa ilişkin ayrıntılı, kapsamlı ve zamana yayılmış bir bakış açısı elde etmek istiyorsa gözlem yöntemini kullanabilir (Bengtsson, 2016; Crabtree ve Miller, 1999; Fossey vd., 2002).

Araştırma yapılan konuya tarafsız olarak yaklaşan araştırmacı, gözlediği olguları yaşandı̆̆ haliyle ve değiştirmeden gözleyip kaydetmelidir. Tarafsız gözlem araştırmanın güvenirliğini ve inandırıcılığını artırır. Bununla birlikte araştırmacının tamamen tarafsız gözlem yapması oldukça zordur; araştırmacının önyargıları, geçmiş deneyimleri ve gözlenen olgu hakkındaki bilgisi gözlem kayıtlarına yansıyabilir (Maxwell, 2008; Neuman ve Robson, 2014; Shenton, 2004). Gözlemler kaydedilirken araştırmacı gözlemin doğasını, kim tarafindan yapıldığını, hangi amaç için, nerede, ne zaman, nasıl bir bakış açısıyla yapıldığını ve ne tür araç-gereçlerin kullanıldığını araştırma raporunda belirtmelidir (Hatch, 2002; Klenke, 2016). Gözlem çeşitleri katılımc1, katılımcı olmayan gözlem ve gizil gözlem gibi farklı çeşitlerde olabilir. Katılımcı gözlemde araştırmacı, incelenen olgunun bir parçasıdır. Fenomenolojik çalışmalarda genellikle katılımcı gözlem kullanılır. Katılımcı olmayan gözlem ise araştırmacının gözlem yapılan mekânda olduğu ancak olay ve olgulara dahlinin olmadığ 1 durumlarda kullanılır. Etnolojik çalışmalarda katılımcı gözlem sıklıkla kullanılır. Gizil gözlem ise araştırmacının, incelediği olay ve olguyu uzaktan takip ettiği, izlenenlerin ise takip edildiğini bilmedikleri durumlarda kullanılır. Kültürel araştırmalar veya vaka analizleri bu türden gözlem yapılmasını gerektirebilir (Golafshani, 2003; Morse, 2016; Patton, 1990; Seidman, 2006; Strauss ve Corbin, 1990).

\section{Doküman/Metin Analizi}

Araştırmada incelenen olgu veya olaylarla ilintili bilgiler içeren yazılı belgelerin ayrıntılı olarak taranması ve bu bilgilerden yeni bir bütünlük oluşturulması, doküman/metin analizi olarak adlandırılır (Creswell, 2002). Araştırılan konu ile ilgili literatür taramasını da içeren doküman analizi, araştırmacının yaptığı gözlem ve görüşme kayıtları ile diğer belgelerin sistematikleştirilmesini sağlar. Bu analiz yöntemi araştırmacı için zaman ve diğer kaynaklarda tasarruf sağlarken, incelenen olgu ve olayların da önem sırasının oluşturulmasını, veri kaynaklarının tasnif edilmesini ve yeni veri setleri oluşturulmasını da kolaylaştırır (Baxter ve Jack, 2008; Crabtree ve Miller, 1999; Guba ve Lincoln, 1994). Örneğin kadına yönelik şiddet ile ilgili bir araştırmada evlilik ve diğer adli istatistiklerin, emniyet verileri ve sosyal hizmet dosyalarının incelenmesi yerinde olacaktır. Bunun yanında araştırma konusuyla ilgili raporlar, kitaplar, arşiv dosyaları, video ve ses kayıtları, görsel materyaller gibi belgeler de metin analizi yolu ile kullanışlı verilere dönüştürülebilir (Merriam, 1998). 
Veri toplama basamağında elde edilen veriler, literatürde yer alan farklı kaynaklardan doğrulanmalıdır. Eğer literatürde yer almayan, özgün ve yeni bir problem üzerinde çalış1lıyorsa, probleme kaynaklık edebilecek farklı çalışmalardan destek alınması gerekebilir. Veri toplama sürecinde çeşitli veri toplama yöntemlerinin bir arada kullanılması, süreçten en iyi şekilde faydalanılmasının yolunu açtığı gibi elde edilen bulguların geçerliği ve güvenirliğinin artırılması için de önemlidir. Ayrıca elde edilen sistematik veriler, analiz aşamasında araştırmacıya önemli bir kolaylık oluşturacak ve zaman kazandıracaktır (Malterud, 2001; Miles ve Huberman, 1994; Silverman, 2016).

\section{Verilerin Analizi}

Araştırma sürecinde toplanan veriler genellikle betimsel, içerik, söylev ve metin analizi gibi farklı ayrıştırma işlemlerine tabi tutulurlar. Betimsel analiz, genellikle nitel veri seti üzerinde detaylı ayrıştırma gerektirmeyen verilerin işlenmesinde kullanılır. Araştırma katılımcılarının demografik özellikleri ile farklı niteliklerinin tasvir edilmesi, bir kentin genel özelliklerinin anlatılması, bir kişinin yaşam öyküsünün özetlenmesi gibi durumlar, betimsel analizdir (Miles ve Huberman, 1994). İçerik analizi, toplanan verilerin daha ayrıntılı incelenmesini ve bu verileri açıklayan kavram, kategori ve temalara ulaşılmasını gerektirir. İçerik analizinde, toplanan verilere odaklanılır; veri setinde sıklıkla tekrarlanan veya katılımcının yoğun vurgu yaptığı olay ve olgulardan kodlar çıkarılır. Kodlardan kategorilere ve kategorilerden de temalara gidilir. Kısaca birbirine benzediği ve birbiri ile ilişkisi olduğu tespit edilen veriler (kodlar) belirli kavramlar (kategoriler) ve temalar çerçevesinde bir araya getirilerek yorumlanır. İçerik analizinde katılımcıların görüşlerinin muhtevası sistematik bir şekilde ayrıştırılır (Bengtsson, 2016; Crabtree ve Miller, 1999; Merriam ve Grenier, 2019).

Nitel araştırmalarda araştırmanın genel yaklaşımlarının dışında araştırmacının amacına göre söylev analizi ve metin analizi gibi farklı veri analiz planı geliştirme ihtiyacı da ortaya çıkabilmektedir. Söylev analizi, belirli bir kişinin ses veya görüntü kayıtlarından hareketle belirli problemleri çözmeye odaklanan bir analiz yöntemiyken, metin analizi farklı metinler üzerinde detaylı incelemeler yaparak problemin çözülmesidir (Golafshani, 2003; Seidman, 2006; Silverman, 2016).

Nitel veri analizinde genellikle üç yöntem önerilmektedir. İlk olarak, toplanan verilerin özgün şekline mümkün olduğunca bağlı kalınması esastır. Gerektiğinde katılımcı ifadelerinin doğrudan alıntı yapılarak verilerin sunulması, söz konusu özgünlüğün geçerliğini arttırır. İkinci yöntemde ise, veriler betimsel bir yaklaşımla sunulmakla birlikte, bazı kodların belirlenmesi, kodlardan kategorilere ve kategorilerden temalara gidilmesi söz konusudur. Ayrıca bu yöntemde temalar arasında ilişkiler de kurulur. Üçüncü yöntemde araştırmacı betimleme ve tematik analizin yanında kendi yorumlarını da kullanarak verileri analiz eder. Aynı araştırmada üç yöntem ayrı ayrı veya bir arada kullanılarak da veri analizi yapılabilmektedir (Baltac1, 2017; Creswell, 2002; Eysenbach ve Köhler, 2002; Miles ve Huberman, 1994).

Nitel araştırmalarda toplanan verilerin analizinde yaygın olarak betimsel analiz veya içerik analizi kullanılır. İçerik analizi, araştırmanın özüne ilişkin kalıpları, temaları, önyargıları ve anlamları belirlemek hedefiyle verilerin dikkatli, detaylı ve sistematik olarak incelenmesi ve yorumlanmasidır. İçerik analizinde amaç, katılımcıların görüşleri ile dosya ve belge incelemesi yoluyla elde edilen verileri açıklayabilecek kavramlara ve ilişkilere ulaşmaktır. Betimsel analizle özetlenen ve yorumlanan veriler, içerik analiziyle derinlemesine bir işleme tabi tutulur ve yeni kavramlar veya kavramlar arası ilişkiler keşfedilir. İçerik analizinde birbirine benzeyen verileri, belirli kavramlar ve temalar çerçevesinde bir araya getirmek ve bunları okuyucunun anlayabileceği bir biçimde düzenlemek esastır (Baltacı, 2017; Guba ve Lincoln, 1994; Maxwell, 2008; Pope vd., 2006).

\section{İçerik Analizi}

İçerik analizi tümevarımcı bir analiz türü olması sebebi ile araştırılan olgu veya olayın kökenlerine odaklanır. Kodlama yoluyla verilerin altında yatan kavramlar ve bu kavramlar arasındaki ilişkiler ortaya çıkarılır. Nitel araştırmada araştırmacı topladığı tanımlayıcı ve ayrıntılı verilerden yola çıkarak probleme ilişkin temaları keşfetme, elde ettiği verileri anlamlı ve sistematik yapılara 
dönüştürme, yani bu verilerden hareketle bir kuram oluşturma veya bir kuramı doğrulama çabası içindedir. İncelenen olay veya olguya esas oluşturabilecek bir kuramın olmaması durumunda tümevarımcı analiz, yani kodlamaya dayalı içerik analizi gereklidir (Baltacı, 2017; Şimşek ve Yıldırım, 2011).

Veriler arasında yer alan anlamlı bölümlere (bir sözcük, cümle, paragraf gibi) araştırmacı tarafından isim verilmesi iş ve işlemleri kodlama olarak ifade edilir. Kodlama süreci; elde edilen verileri bölümlere ayırmayı, incelemeyi, karşılaştırmayı, kavramlaştırmayı ve ilişkilendirmeyi zorunlu kılar. Veriler arasında yer alan anlamlı bölümlere (bir sözcük, cümle, paragraf gibi) ve olaylara verilen anlamlar ise kavram olarak tanımlanır. Kavramlar içerik analizinin temel analiz birimini oluştururlar. İçerik analizinde elde edilen kavramların birbirleriyle belirli bir ilişki içinde sınıflandırılması kategorilere ayırma olarak ifade edilir. Kategoriler ise bir tema altında toplanırlar. Kategorilerin incelenmesi sonucunda birbirleriyle olan ilişkileri ortaya çıkarılır ve bu ilişkilerin daha üst düzey bir gruplamayı gerektirdiği durumlarda temalardan söz edilir. Temalar içerik analizinde elde edilen kavramlardan daha soyuttur ve geneldir ve esasen araştırma probleminin boyutlarını göstermesi bakımından önemlidir (Merriam ve Grenier, 2019; Miles ve Huberman, 1994; Patton, 1990).

İçerik analizinde görüşme, gözlem veya dokümanlar yoluyla elde edilen veriler, dört aşamada analiz edilir: (1) verilerin kodlanması, (2) kod, kategori ve temaların bulunması, (3) kod, kategori ve temaların düzenlenmesi ile (4) bulguların tanımlanması ve yorumlanması (Eysenbach ve Köhler, 2002; Miles ve Huberman, 1994).

Verilerin Kodlanması: Verilerin kodlanması aşamasında araştırmacı, topladığı verileri inceler ve veri setini anlamlı bölümlere ayırmaya, her bölümün hangi kavramı karşıladığını keşfetmeye çalışır. Kendi içinde anlamlı yapılar oluşturan her bir bölüme araştırmacı tarafından isim verilir. Bölümler çoğu durumda bir kelime, cümle veya söz öbeği olabilir. Veri kodlama sürecinde sıklıkla araştırmacının veri setini birkaç kez okuması gerekebilir. Detaylı okumalarla katılımcıların tekrarladığı sözcük veya söz öbeklerindeki anlama ulaşmak kolaylaşır. Kodlama süreci oldukça dinamik bir şekilde işlemekte ve araştırmacı tekrar tekrar veri setine dönerek kodlama işlemini yürütmektedir. Tekrarlı kodlamalar, veri setinin derinliği ve kapsamının büyüklüğüne göre değişiklik arz etse de kategoriler ve temalar oluştuktan sonra bile yeni kodlara rastlama olasılığı olduğundan, çoğu durumda araştırmacının tüm veri analizi süresince kodlama yaptığı görülür (Kvale, 1994; Morse, 2016; Silverman, 2016).

Miles ve Huberman (1994), kodlamanın üç ayrı süreci ihtiva etmesi gerektiğini bildirir. Buna göre, (1) daha önceden belirlenmiş kavramlara göre yapılan kodlama söz konusu iken, (2) verilerden çıkarılan kavramlara göre yapılan kodlama ile (3) araştırma probleminin genel çerçevesine göre yapılan kodlama da olabilmektedir. Kodlama işlemlerinde araştırmacının titiz çalışması sonucu ayrıntılı analizler gerçekleştirilse de kodlamanın ne kadar ayrıntılı olması gerektiği önemli bir problemdir. Araştırmanın amacına ve niteliğine göre farklılık gösterse de kodlama ayrıntısı, araştırmanın tutarlığını, inandırıcılığını ve güvenirliğini doğrudan etkilemektedir. Birebir iletişim süreçlerini içeren araştırmalarda ayrıntılı kodlama yapmak gerekirken, toplumca bilinen ya da farklı bir konudaki araştırmalarda bu denli ayrıntılı kodlama yapılması gerekmeyebilir (Malterud, 2001; Miles ve Huberman, 1994; Sandelowski, 1986).

Kategori ve Temaların Belirlenmesi: Nitel veri analizinin ilk aşamasında keşfedilen kodlardan hareketle veri setini daha genel düzeyde açılayabilen ve kodları belirli kategoriler altında toplayabilen temaların belirlenmesi gereklidir. Bu kapsamda tematik kodlama denilen daha soyut bir kodlama söz konusudur ve öncelikle ilk aşamada keşfedilen kodlar bir araya getirilir ve aralarındaki ortak özellikler belirlenmeye çalışılır (Baltacı, 2017; Strauss ve Corbin, 1990). Tematik kodlama, farklı özellikleri olan kodların benzerlik ve farklılıklarının tespit edilmesi ve bu dolayımda birbiriyle ilişkili olan kodların gruplanması söz konusudur. Bu gruplama bir kategorilere ayırma işlemidir. Aynı türden kategoriler ise temaları oluşturur. İç tutarlılık, tematik kodlama yapılırken göz önüne alınması gereken önemli bir durumdur. Yani, belirlenen temaların dayandığı veri setinin anlamlı bir ilişki kurma derecesi, tematik kodlamada göz önüne alınmalıdır. Ayrıca dış tutarlılık olarak adlandırılan, belirlenen temaların tümünün araştırmada elde edilen verileri anlamlı bir biçimde açıklayabilme derecesi de önemlidir. Yani belirlenen 
temalar, birbirinden ayrı olmakla birlikte, kendi içlerinde anlamlı bir bütün oluşturabilmelidir. Kategori ve temalar belirlendikten sonra tekrar kodlama işlemi yapılarak verilerin kodlara göre düzenlenmesi yapılmalıdır (Merriam ve Grenier, 2019; Patton, 1990; Silverman, 2016).

Verilerin Kodlara, Kategorilere ve Temalara Göre Düzenlenmesi: Ayrıntılı kodlama ve tematik kodlama neticesinde, araştırmacı topladığ 1 verileri anlamlı bir şekilde düzenleyebileceği sistematik bir yapı oluşturur. Daha sonra araştırmacı, bu yapıyı temel alarak topladığı verileri yeniden düzenleme yoluna gider. Verilerin yeniden düzenlenmesi, bazı durumlarda ayrıntılı kodlama ile tematik kodlamanın sağlamasının yapılmasını da gerektirebilir. Veri düzenleme aşamasında araştırmacı öncü bulgulara erişir ve söz konusu bulgulara göre verileri yeniden tanımlamak ve yorumlamak mümkün olabilir. Verilerin okuyucunun anlayabileceği bir dille tanımlanması, açıklanması ve sunulması önemlidir. Genellikle araştırmaların bulgular bölümünde yer alan bilgilere odaklanılan bu aşamada araştırmacı, kendi görüş ve yorumlarına yer vermez ve toplanan bilgileri işlenmiş bir biçimde okuyucuya sunar (Baltac1, 2017; Denzin ve Lincoln, 2008a; Miles ve Huberman, 1994; Şimşek ve Yıldırım, 2011).

Bulguların Yorumlanması: Nitel araştırmalar, araştırmacının şahsi deneyimlerinin sunulduğu ve yaşanmışlıkların da önemli veri sunabildiği araştırma yönelimidir. Bu açıdan araştırmacı, incelenen olay veya olguya yakın ve hatta çoğu durumda iç içe olduğu ve olguya ilişkin ilk elden yaşantılar tecrübe ettiği için, onun yapacağı yorum ve aktarımlar özel bir değer taşır. Bu nedenle araştırmacı bu son aşamada; topladığ 1 verilere anlam kazandırmak ve bulgular arasındaki ilişkileri açıklamak, neden-sonuç ilişkilerini kurmak, bulgulardan birtakım sonuçlar çıkarmak ve elde edilen sonuçların önemine ilişkin açıklamalar yapmak zorundadır. Yorumlama, araştırmacının probleme ilişkin içinde oluşan farkındalık durumu ve probleme içselleştirilmiş çözüm üretme eylemidir (Connelly, 2016; C. Marshall ve Rossman, 2014; Seale, 1999).

\section{Betimsel Analiz}

Betimsel analizde amaç, görüşme ve gözlem sonucu toplanan verilerin düzenlenmiş ve yorumlanmış bir şekilde okuyucuyla buluşturulmasıdır. Çoğu betimsel analizde veriler önceden belirlenmiş temalara göre sınıflandırılır, sınıflandırılan verilere ilişkin bulgular özetlenir ve özetler ise araştırmacının öznel birikimi ile yorumlanır. Ayrıca araştırmacı bulgular arasında neden-sonuç ilişkisi kurar ve gerekirse olgular arasında yapısal farklılık analizleri ile karşılaştırmalar yapar (Kitzinger, 1995; Kvale, 1994). Betimsel analiz dört aşamalı bir süreci ifade eder. (1) Betimsel analiz için bir çerçeve oluşturma: Araştırma sorularından, araştırmanın kavramsal çerçevesinden ya da görüşme ve/veya gözlemde yer alan boyutlardan hareketle veri analizi için bir çerçeve oluşturulur. Bu çerçeveye göre verilerin hangi kategori ve temalar altında toplanacağ 1 , hangi temaların hangi kategorilere göre düzenleneceği ve sunumun nasıl olacağı belirlenir. Önceden hazırlanmış bir kavramsal çerçevenin olmadığ durumlarda, betimsel analizi kullanmak güçtür. Böyle bir durumda belirlenecek temalar, veri kaybına ve yanlış veri düzenlenmesine neden olabilir. Bu açıdan betimsel analiz yapacak araştırmacının öncelikle araştırma problemine ilişkin yoğun bilgi içeren bir kavramsal çerçeve hazırlaması gereklidir. (2)Tematik çerçeveye göre verilerin işlenmesi: Bu aşamada, daha önce oluşturulan tematik çerçeveye göre elde edilen veriler ayrıntılı bir şekilde okunarak düzenlenir. Buna göre bazı veriler tematik çerçevenin dışında kalabilir veya temaların kapsadığı alan için önemli olmayabilir. Ayrıca bu aşamada, daha sonra sonuçlar yazılırken kullanılacak doğrudan alıntılar ve güçlü örnekler de seçilir. (3) Bulguların tanımlanması: Düzenlenen veriler tanımlanır ve gerekli yerlerde doğrudan alıntılarla desteklenir. (4) Bulguların yorumlanması: Tanımlanan bulguların açıklanması, ilişkilendirilmesi ve anlamlandırılması bu aşamada yapılır (Crabtree ve Miller, 1999; Creswell, 2002; Hay, 2000; Marshall ve Rossman, 2014; Miles ve Huberman, 1994; Seidman, 2006).

Bir nitel araştırmanın gücü, araştırma problemini çözümleme biçiminden ziyade, okuyucuyu problemin doğru çözümünün araştırma kapsamında sunulduğuna inandırmaktır. İnandırıcılık ve tutarlılık, nitel bir araştırmanın tekrar edildiğinde benzer sonuçların alınmasını garanti etme durumudur. Nitel araştırmaların inandırıcı olması, onların geçerli ve güvenilir veriler sunması ile ilgilidir (Connelly, 2016). İlerleyen bölümde nitel araştırmada kullanılagelen geçerlik ve güvenirlik kavramlarına yer verilmişsir. 


\section{Nitel Araştırmada Geçerlik ve Güvenirlik}

Bilimsel araştırmaların kabul görmesi için belirli düzeyde geçerli ve güvenilir olması gereklidir. Araştırmalarda kullanılan veri toplama araçlarının, araştırma deseninin ve veri analizinin geçerliği ve güvenirliğinin belirlenmesi, araştırmanın inandırıcılığını ve kabul görme derecesini etkilemektedir. Nicel araştırmaların geçerliği ve güvenirliği için farklı ölçme yöntemleri bulunmasına rağmen nitel araştırmalarda kesin bir geçerlik ve güvenirlik tespiti yapmak mümkün olmamaktadır (Guba ve Lincoln, 1994; Shenton, 2004). Nitel araştırma çoğunlukla bir olgunun var oluş dinamiklerine ve anlamına yönelirken, nicel araştırma bir olgunun ne derece var olduğunu belirlemeye çalışmaktadır. Yani nitel araştırma araştırılan olgu ve olayların niteliğini ön plana çıkarırken, nicel araştırma nicel değişimi öne çıkarır.

\section{Nitel Araştırmada Geçerlik}

Geçerlik araştırma sonuçlarının doğruluğunu veya problemi çözme becerisini konu edinir. Nitel araştırmada geçerlik, araştırmacının konu edindiği problemi olabildiğince tarafsız bir şekilde çözüme kavuşturma derecesidir. Bu durumda elde edilen verilerin gerçekte var olan durumu yansıtma derecesi önemlidir. Araştırma problemini bir bütün olarak ele almak veya incelenen olgunun tüm özelliklerine yoğunlaşmak, önemli geçerlik ölçütleridir. Bunun yanında katılımcılarla yapılan görüşmelerde sık sık "Bunu mu kast ettiniz?" veya "Sözlerinizden bunu mu anlamalıyım?" gibi geri dönüşlerle katılımcı teyidi almak geçerliği artıır. Ayrıca araştırmacının veriler üzerinde başka bir uzmanın incelemelerine izin vermesi, yani meslektaş veya uzman teyidini sağlaması da geçerliğe olumlu katkı sağlamaktadır (Denzin ve Lincoln, 2008a; Sandelowski, 1986). Nitel araştırmalarda geçerlik, iç ve dış geçerlik olarak iki şekilde incelenir. İç geçerlik: Araştırma sonuçlarına ulaşırken izlenen sürecin, çalışılan gerçekliği ortaya çıkarmadaki yeterliliğidir. "Araştırmacı olarak gözlediğimizi sandığımız olaylar ya da anladığımızı düşündüğümüz olgulara ilişkin yorumlarımız gerçek durumu tüm ayrıntıları ile yansıtıyor mu? Araştırma bulguları kendi içinde tutarlı ve anlamlı mı? Bulguları teyit etmede kullanılan, belirli ilkeler, kurallar veya stratejiler var mı? Açık olmayan veya ilişkileri belirlenememiş olgular ya da olaylar var mı? Bulgular araştırmaya katılan bireyler tarafından gerçekçi bulunmuş mu ve teyit edilmiş mi?” gibi sorular iç geçerliği artırmaya yöneliktir (Morse, 2016; Patton, 1990; Silverman, 2016).

Kabul edilebilir bir nitel araştırmada, araştırmacının hem veri toplama süreçlerinde hem de verilerin analizi ve yorumlanması iş ve işlemlerinde belirli ölçüde tutarlı olması ve bu tutarlılığ nasıl sağladığını ayrıntılı olarak açıklaması beklenir. Ayrıca araştırmacının nitel araştırma sürecini eleştirel bir gözle sorgulaması ve olası hataları en aza indirebilmek için sürece hâkim olması da önemlidir. Çalışmadaki kontrollerin nasıl yapıldığı araştırma yöntemi bölümünde detaylı ve açık bir şekilde rapor edilmelidir (Shenton, 2004). İç geçerliğin sağlandığ 1 araştırmalar akademik çevrelerde önemli ölçüde kabul edilse de dış geçerliğin sağlanması da bir şart olarak koşulur. Elde edilen sonuçların benzer gruplara ya da ortamlara aktarılabilirlik veya transfer edilebilirlik derecesi dış geçerlik kavramıyla ifade edilmektedir. Dış geçerlik araştırma sonuçlarının evrensel niteliğe erişmesi veya genellenebilirliği olarak da adlandırılabilir. Sosyal olayların, içinde bulunan ortama göre değiştiği varsayımından hareketle hiçbir araştırma sonucunun başka bir duruma doğrudan genellenemeyeceği söylenebilir. Ancak burada bahsedilen genelleme durumu, Popper'in tekrarlanabilirlik ilkesinin gereği olan ve olguların benzer zamanlarda birbirine benzeştiği, benzeşen olayların ise farklı zamanlarda benzer sonuçlar verebilecek ölçüde evrensel olduğudur (Baltac1, 2018; Creswell, 2002; Guba ve Lincoln, 1994; Merriam, 1998; Teddlie ve Yu, 2007). Nicel araştırmalarda evrensel genelleme doğrudan yapılabilirken, nitel araştırmada genelleme ancak dolaylı yorumlamalar ve benzetmelerle yapılabilir. Araştırmasının sınırlı ölçülerde genellenebilir olmasını ve bu kapsamda dış geçerliği sağlamak isteyen bir araştırmacı bazı soruları dikkate almalıdır: "Araştırma örnekleminin, ortamının ve süreçlerinin özellikleri başka örneklemlerle karşılaştırma yapabilecek düzeyde ayrıntılı olarak tanımlanmış mıdır? Örneklem genellemeye izin verecek ölçüde çeşitlendirilmiş midir? Araştırma sonuçlanı araştırma sorusu ile ilgili kuramlarla tutarlı mıdır? Araştırma bulguları benzer ortamlarda kolaylıkla test edilebilir mi?" Elbette nitel araştırma yapan her araştırmacının yukarıda anılan sorulara uygun cevaplar vermesi mümkün olmayabilir. Ancak araştırma sonuçlarının benzer durum, olay ve ortamlara genellenebilmesi için 
araştırmacının okuyucuyu yaptığı çalışmanın tüm aşamaları hakkında ayrıntılı bir şekilde bilgilendirmesi ve okuyucuyu ikna etmesi gerekmektedir (Bogdan ve Biklen, 1997; Connelly, 2016; Creswell, 2002; Golafshani, 2003; Hay, 2000; Makatouni, 2002; Morgan ve Smircich, 1980; Silverman, 2016; Şimşek ve Yıldırım, 2011).

\section{Nitel Araştırmada Güvenirlik}

Araştırma sonuçlarının tekrar edilebilirliği, güvenirlik kavramıyla ilişkilidir. Yani "çalışma ikinci kez yürütülmüş olsa yine aynı sonuçlara ulaşılabilir mi?" sorusu araştırmalarda sıklıkla rastlanılan güvenirlik sorununa işaret eder. İnsan tutum ve davranışlarının dinamik ve değişken doğası gereği çoğu araştırma tekrarlanamaz, ancak farklı ölçme durumları ile inandırıcılığı arttırabilir. İnandırıcılığın ön koşullarından olan güvenirlik, araştırmalarda mutlaka sağlanması gereken bir koşuldur. Güvenirliği düşük olan bir araştırmanın bilimsel değeri olmadığı gibi, güvenirliğin yüksek olması da yapılan araştırmanın amaca uygunluğunun (geçerliğinin) garantisi olamamaktadır. Ancak bir araştırmanın geçerli olabilmesi için öncelikle güvenilir olması gereklidir. Bu açıdan bir araştırmanın güvenirliği: (1) zamana göre değişmezliği (süreklilik), (2) bağımsız uzmanlar veya puanlayıcılar arasındaki uyumu (puanlayıcı tutarlığı) ve (3) iç tutarlığının sağlanması ile mümkündür (Baxter ve Jack, 2008; Miles ve Huberman, 1994; Patton, 1990; Sandelowski, 1986).

Güvenirlik, dış güvenirlik ve iç güvenirlik olarak iki unsura sahiptir. Dış güvenirlik, araştırmanın benzer ortamlarda yinelendiğinde benzer sonuçlara ulaşılması olarak adlandırılabilir. Dış güvenirliğin sağlanması için araştırmanın şeffaf bir şekilde rapor edilmesi, katılımcıların ve diğer veri kaynaklarının açık bir şekilde belirtilmiş olması gereklidir (Connelly, 2016). Ayrıca araştırmacı kendi konumunu ve yorumlarına kaynaklık eden olay, olgu ve kuramları da araştırma raporunda açı ve anlaşılır bir şekilde bildirmiş olmalıdır. Bunun yanında araştırma sürecinde oluşan siyasal, sosyal ve ekonomik değişiklikler ile katılımcıların psikolojik ve demografik özelliklerinin de araştırma raporunda tanımlanmış olması dış güvenirliğin sağlanması için önemlidir. Araştırma bulgularının, araştırmanın kavramsal çerçevesiyle uyumlu olması ve araştırma sonuçlarının farklı araştırma sonuçlarıyla desteklenmesi de dış güvenirliğe artıran bir durumdur (Golafshani, 2003; Maxwell, 2008; Shenton, 2004). Ayrıca araştırmanın yöntem bölümünde veri toplama araçları, veri toplama süreci ve verilerin nasıl analiz edildiğinin ayrıntılı olarak açıklanması dış güvenirliğe katkı sağlar. İleri dönemlerde farklı araştırmacıların aynı veri setini kullanarak benzer sonuçlara ulaşması durumu ise iç güvenirlik olarak adlandırılabilir. İç güvenirliğin sağlanması için: (1) elde edilen verilerin öncelikle betimsel bir sistematikle direkt olarak araştırma raporunda sunulması gereklidir, (2) aynı araştırmaya birden fazla araştırmacının dâhil edilmesi, araştırmanın bakış açısını ve eleştirel yorum yetisini güçlendireceğinden iç güvenirliği arttırır, (3) özellikle gözlem yoluyla toplanan bulguların görüşmeler yoluyla sağlamasının yapılması; ayrıca katılımcılar ile uzmanların da bu görüşmelerin doğruluğunu teyit etmeleri gereklidir, (4) toplanan verilerin analizinde başka araştırmacı ve uzmanlardan analiz desteği alma veya farklı kodlayıcılar ile puanlama tutarlı̆̆ 1 artırılmalıdır, (5) araştırmanın verileri toplanmadan önce oluşturulmuş ve ayrıntılı olarak tanımlanmış bir kavramsal çerçeveye bağlı olarak yapılan veri analizi de iç güvenirliğe katkı sağlayacaktır (Baltac1, 2017; Baxter ve Jack, 2008; Creswell, 2002; Guba ve Lincoln, 1994; Kitzinger, 1995; Kvale, 1994; Merriam ve Grenier, 2019; Neuman ve Robson, 2014; Silverman, 2016).

Son olarak geçerlik ve güvenirliğin sağlanabilmesi için, araştırma yürütülürken örneklemin yeterli büyüklükte seçilmesi, birden çok araştırmacı ile konunun ele alınması, daha çok kaynak ve görüşe başvurulması, elde edilen verilerin iyi bir şekilde saklanması ile çalışılan ortamın ve araştırmacının konumunun tam olarak araştırma raporunda belirtilmesi ve çalışmanın araştırmacının şahsi görüşlerinden etkilenmeksizin tarafsız bir şekilde yürütülmesi gerekmektedir (Baltac1, 2018; Denzin ve Lincoln, 2008b).

\section{Sonuçların Raporlaştırılması}

Sosyal gerçeklik belirli bir zamanda, belirli bir mekân veya sosyal bağlamda beliren olgu ve olayların dinamik yapısına dayalı karmaşık bir yapıdır. Bu denli karmaşık bir yapı, farklı ve birbiriyle 
ilintili çok sayıda sorunun ortaya çıkmasını sağladığı gibi, farklı çözüm yolları üretecek araçların da var olmasını mümkün kılar. Sosyal gerçekliğin karmaşık doğası, nitel bir araştırma ile problemin çözümünü olanaklı kılarken, çözümden hareketle belirli genellemelere ulaşılmasını da güçleştirir. Çünkü belirli ve sınırlı bir örneklem grubu üzerinde yürütülen nitel çalışmaların, tüm evreni temsil edecek güce sahip olamayacağı aşikârdır. Ayrıca çoğunlukla tek veya birkaç kişilik küçük gruplardan elde edilen veriler ile istatistiki açıdan genelleme yapılması da doğru değildir (Denzin ve Lincoln, 2008b; Hatch, 2002; Merriam ve Grenier, 2019).

Nitel araştırma sonucu elde edilen bulgular, çoğunlukla araştırma probleminin derinlemesine keşfedilmesini ve sosyal gerçekliğin farklı yönlerinin anlaşılmasını sağlar. Bu bakımdan nitel araştırmadan elde edilen verilerin tüm ayrıntıları ile raporlaştırılması gereklidir. Özellikle farklı kodların nasıl bir araya geldiği, kodlardan kategorilere nasıl ulaşıldığı ve kategorilerin temaları oluşturma süreci bir nitel araştırmada mutlaka bulunmalıdır. Bu sayede araştırmanın geçerliği artarken, güvenirliği ve tutarlılığına da katkı sağlanmış olur. Nitel araştırmalar, nicel araştırmaya göre daha fazla detay içerdiğinden çoğunlukla daha uzun yazılırlar. Akademik yazma ilkeleri gereği, nitel araştırma raporlarında kelime sayısı ve cümle kullanımlarında önemli bir tasarruf ve indirgemenin yapılması gereklidir. Katılımcının her söylediği önemli olsa da araştırmacı, en önemli noktalara eğilip o cümleleri seçmeli ve raporunda önem arz eden ifadelere yer vermelidir. Nitel araştırma raporlarında yinelenmiş ifadelerden veya aynı konunun tekrarı olabilecek durumlardan kaçınılması için farklı zamanlarda raporu okumak veya farklı okurların eleştirel görüşlerini almak için raporu okutmak önemlidir (Bogdan ve Biklen, 1997; Connelly, 2016; Crabtree ve Miller, 1999; Eysenbach ve Köhler, 2002; Fossey vd., 2002; Mallat, 2007).

Veri analizi kapsamında elde edilen sonuçlar, araştırmacıya önemli bir deneyim ve bakış açısı kazandırır. Rapor sonucunda araştırmacı, kendi deneyimlerini paylaşmalı ve benzer çalışmalar yapacak araştırmaların karşılaşabileceği olası güçlükleri de açıklamalıdır. Bu noktada araştırmanın neden yapıldığından ziyade, araştırma sonuçlarının yeni ve farklı sorunları görünür kılması önemlidir (Baxter ve Jack, 2008; Seidman, 2006; Şimşek ve Yıldırım, 2011).

\section{Tartışma, Sonuç ve Öneriler}

Bilimsel sürecin en önemli özelliği bilim insanının herhangi bir sınırlama olmaksızın, kendi potansiyelini kullanma becerisini göstermesidir. Araştırmacıların takip edebileceği ya da takip etmesi gereken standart bir araştırma yöntemi olmasa da yaygın olarak kullanılan yöntemleri taklit ederek veya kendince yöntemler bularak farklı problemlere çözüm bulmak olanaklıdır. Birçok araştırmacı karşılaştığ 1 problemi çözmek ya da bilinmeyeni keşfetmek için farklı ve daha önce denenmemiş yöntemler kullanmıştır. Sosyal bilimlerde kullanılan nicel yöntemler genellikle evrensel genellemelere ulaşma çabasındayken, nitel yöntemler belirgin bir özel alanı inceleme eğilimindedir. İnsan ve topluma ait olgu ve olayların, açıklanmaktan çok anlaşılmayı ve keşfedilmeyi bekleyen karmaşık anlamlar dünyası olması sebebiyle nicel yöntemlerden ziyade nitel araştırmanın özgün formuna yatkın olduğu söylenebilir. Dolayısıyla nitel araştırmalar dünyanın sosyal yönü ile ilgilenir ve insanların olay ve olgular karşısında neden böyle davrandığını, tutum ve davranışların arkasında yatan nedenlerin neler olduğu, kişi ve toplumların gerek birbirlerinden gerekse çevrelerinde olup bitenden nasıl etkilendiği, kültürlerin neden ve nasıl oluştuğu ve geliştiği, sosyal grupların nasıl iletişim kurduğu gibi özellikli sorulara cevap arar.

Teori ve hipotezlere dayanan (deduktif) nicel araştırmalardan ziyade nitel araştırmalarda kavram ve teorilerin oluşumuna (induktif) odaklanılmaktadır. Nicel araştırmadan farklı olarak nitel araştırma kişilerin kanaatleri, tecrübeleri, algıları ve duyguları gibi sübjektif verilere yönelmektedir. Sübjektif verileri analiz eden nitel araştırma, olay ve olgulara ilişkin anlamlar oluşturma çabasındadır. Ayrıca bir sosyal olayı doğal ortamı ve doğal oluşumu içinde tasvir eden nitel araştırmalar, deneysel süreçlere bağımlı olan nicel araştırmalar gibi olayın değişkenlerine değil olayın arkasındaki nedenleri kavramaya çalışır. Nitel araştırma "niçin, nasıl ve ne şekilde" gibi soyut sorulara cevap ararken nicel araştırma "ne kadar, ne miktarda, ne kadar sık ve ne kadar yaygın" gibi somut sorulara cevap arar. Nitel 
araştırma yapanların iyi gözlem yapabilme, insanlarla 1lımlı ilişkiler kurabilme, karşısındakini etkili bir şekilde dinleyebilme ve verileri iyi analiz edebilme gibi becerilerinin olması gereklidir.

Nitel araştırmalarda evrensel genellemelerden ziyade araştırma sonuçlarının sınırlandırılması ve farkl1 durumlara uyarlanabilen, tekrarlanabilen genellemelere ulaşılması hedeflenmektedir. Nitel araştırmalarda sosyal alanda cereyan eden olay ve olgular inceleme konusudur. Dinamik yapısı gereği sosyal olaylar duruma, zamana ve mekâna göre değişiklik gösterebilir. Ayrıca nicel araştırmanın evren ve örneklem yöntemlerinden önemli ölçüde farklılık gösteren nitel araştırmalarda çalışma grubu söz konusu olduğundan, araştırma bulgularının evrene genellenebilmesi güçtür. Çünkü nitel araştırmaların çalışma grupları eşsizdir ve benzerlerinin toplumsal yapı içinde bulunma olasılığı düşüktür. Bu sebeple nitel araştırmalarda ancak sınırlı ve özel genellemeler yapılabilmektedir. Sınırlı genelleme yapılırken araştırmanın çerçevesi ve sınırlılıkları dikkate alınmalı ve araştırma raporunda bu sinırlılıklar ayrintılarıla belirtilmelidir.

Nitel bir araştırmanın yaygın olarak kullanılagelen süreçlerini inceleyen bu çalışma kavramsal analiz yöntemiyle yürütüldüğünden, literatürde yaygın olarak kullanılan temel kaynaklar incelenmiş; makale hacmini aşmamak için belirli örneklere yer verilememiştir. Ayrıca bu çalışmada nitel araştırmalarda sıklıkla yapılan yöntemsel yanlışlıklara değinilmemiştir. Bu durum ileride yapılacak karşılaştırmalı yöntemsel analiz çalışmalarının gerekliliğini ortaya koymaktadır. Bu çalışmada temelde akademik çevreler tarafından kabul görmesi olası bir nitel araştırma süreci ele alınmış, nitel araştırmanın araştırmacı tarafından yapılandırılması gereken öznel süreçleri vurgulanmıştır. Nitel araştırmanın karmaşık doğası ve çok farklı durumları detaylandırabilecek esneklikte olması dolayısıyla bu çalışma söz konusu araştırma karakteristiğini tanıtma amacını gütmüştür. İleride yapılacak çalışmaların nitel araştırmanın farklı unsurlarını ayrı ayrı olarak ele alması ve nitel araştırmalarda sıklıkla karşılaşılan yöntemsel eksikliklere değinmesi önerilebilir. Ayrıca literatürde, sosyal olgulardaki dinamik süreçlerin bir nitel araştırma içinde nasıl kurgulanması gerektiğine yönelik kapsamlı çalışmalar olsa da bir nitel araştırma sürecini ele alan bu çalışma literatürdeki kavramsal eksikliği giderme çabalarına katkı sağlamak amacıyla yürütülmüsstür. İleride yapılacak araştırmaların daha fazla örnekler içeren ve özellikle analiz sürecindeki araştırmacı hatalarına yönelen tarzda yürütülmesi önerilebilir. $\mathrm{Bu}$ araştırmada nitel araştırmaların etik boyutlarından bahsedilmemiştir. Etik ilke ve tutumlar araştırmacının sahip olması gereken önemli özelliklerdendir. Bu bakımdan ileride yapılacak çalışmalarda nitel araştırma etiğine yer verilmesi de önerilebilir. 


\section{Kaynaklar}

Antwi, S. K. and Hamza, K. (2015). Qualitative and quantitative research paradigms in business research: A philosophical reflection. European Journal of Business and Management, 7(3), 217225 .

Baltac1, A. (2017). Nitel veri analizinde Miles-Huberman modeli. Ahi Evran Üniversitesi Sosyal Bilimler Enstitüsü Dergisi, 3(1), 1-15.

Baltac1, A. (2018). Nitel araştırmalarda örnekleme yöntemleri ve örnek hacmi sorunsalı üzerine kavramsal bir inceleme. Bitlis Eren Üniversitesi Sosyal Bilimler Enstitüsü Dergisi, 7(1), 231274.

Baxter, P. and Jack, S. (2008). Qualitative case study methodology: Study design and implementation for novice researchers. The qualitative report, 13(4), 544-559.

Bengtsson, M. (2016). How to plan and perform a qualitative study using content analysis. NursingPlus Open, 2, 8-14.

Bogdan, R. and Biklen, S. K. (1997). Qualitative research for education. Allyn \& Bacon Boston, MA

Coffey, A. and Atkinson, P. (1996). Making sense of qualitative data: Complementary research strategies. Sage Publications, Inc.

Connelly, L. M. (2016). Trustworthiness in qualitative research. Medsurg Nursing, 25(6), 435-437.

Crabtree, B. F. and Miller, W. L. (1999). Doing qualitative research. sage publications.

Creswell, J. W. (2002). Educational research: Planning, conducting, and evaluating quantitative. Prentice Hall Upper Saddle River, NJ.

Denzin, N. K. and Lincoln, Y. S. (2008a). Introduction: The discipline and practice of qualitative research.

Denzin, N. K., and Lincoln, Y. S. (2008b). The landscape of qualitative research (C. 1). Sage.

Eysenbach, G., and Köhler, C. (2002). How do consumers search for and appraise health information on the world wide web? Qualitative study using focus groups, usability tests, and in-depth interviews. Bmj, 324(7337), 573-577.

Forrester, M. A. and Sullivan, C. (2018). Doing qualitative research in psychology: A practical guide. New York: Sage.

Fossey, E., Harvey, C., McDermott, F. and Davidson, L. (2002). Understanding and evaluating qualitative research. Australian and New Zealand journal of psychiatry, 36(6), 717-732.

Golafshani, N. (2003). Understanding reliability and validity in qualitative research. The qualitative report, 8(4), 597-606.

Guba, E. G. and Lincoln, Y. S. (1994). Competing paradigms in qualitative research. Handbook of qualitative research, 2(105), 163-194.

Hatch, J. A. (2002). Doing qualitative research in education settings. Suny Press.

Hay, I. (2000). Qualitative research methods in human geography. UK: Oxford University Press. 
Kitzinger, J. (1995). Qualitative research: Introducing focus groups. Bmj, 311(7000), 299-302.

Klenke, K. (2016). Qualitative research in the study of leadership. Emerald Group Publishing Limited.

Kuş, E. (2007). Nicel-nitel araştırma teknikleri: Sosyal bilimlerde araştırma teknikleri: Nicel mi? Nitel mi?. Ankara: Anı Yayıncılık.

Kvale, S. (1994). Interviews: An introduction to qualitative research interviewing. Sage Publications, Inc.

Makatouni, A. (2002). What motivates consumers to buy organic food in the UK? Results from a qualitative study. British Food Journal, 104(3/4/5), 345-352.

Mallat, N. (2007). Exploring consumer adoption of mobile payments-A qualitative study. The Journal of Strategic Information Systems, 16(4), 413-432.

Malterud, K. (2001). Qualitative research: Standards, challenges, and guidelines. The Lancet, $358(9280), 483-488$.

Marshall, C. and Rossman, G. B. (2014). Designing qualitative research. Sage publications.

Marshall, M. N. (1996). Sampling for qualitative research. Family practice, 13(6), 522-526.

Maxwell, J. A. (2008). Designing a qualitative study. The SAGE handbook of applied social research methods, 2, 214-253.

Merriam, S. B. (1998). Qualitative Research and Case Study Applications in Education. Revised and Expanded from" Case Study Research in Education.". San Francisco, CA: Jossey-Bass Publishers.

Merriam, S. B., and Grenier, R. S. (2019). Qualitative research in practice: Examples for discussion and analysis. San Francisco, CA: Jossey-Bass Publishers.

Miles, M. B. and Huberman, A. M. (1994). Qualitative data analysis: An expanded sourcebook. New York: Sage Publications, Inc.

Morgan, D. L. (1996). Focus groups as qualitative research (C. 16). New York: Sage publications.

Morgan, G. and Smircich, L. (1980). The case for qualitative research. Academy of management review, 5(4), 491-500.

Morse, J. M. (2016). Mixed method design: Principles and procedures. New York: Routledge.

Neuman, W. L., and Robson, K. (2014). Basics of social research. Pearson Canada Toronto.

Patton, M. Q. (1990). Qualitative evaluation and research methods. SAGE Publications, inc.

Pope, C., Ziebland, S. and Mays, N. (2006). Analysing qualitative data. Qualitative Research in Health Care, 63-81.

Sandelowski, M. (1986). The problem of rigor in qualitative research. Advances in Nursing Science, $8(3), 27-37$

Seale, C. (1999). Quality in qualitative research. Qualitative Inquiry, 5(4), 465-478. 
Seidman, I. (2006). Interviewing as qualitative research: A guide for researchers in education and the social sciences. Teachers college press.

Shenton, A. K. (2004). Strategies for ensuring trustworthiness in qualitative research projects. Education for information, 22(2), 63-75.

Silverman, D. (2016). Qualitative research. Sage.

Strauss, A. and Corbin, J. (1990). Basics of qualitative research. Sage publications.

Şimşek, H. ve Yıldırım, A. (2011). Sosyal bilimlerde nitel araştırma yöntemleri. Ankara: Seçkin Yayıncilı.

Teddlie, C. and Yu, F. (2007). Mixed methods sampling: A typology with examples. Journal of mixed methods research, 1(1), 77-100. 


\section{Extended Abstract}

\section{Introduction}

In this study, after giving brief information about qualitative research, the basic principles of this research method will be discussed and the qualitative research process will be explained. In this context, self-knowledge will be presented about how to design qualitative research through the question of how should qualitative research be done? Although there are many books and articles on qualitative research methods, the main motivation of this study is the lack of a study on the process of conducting qualitative research. It is predicted that the study will close an important gap in terms of focusing on the mistakes made frequently in many qualitative research studies in the literature and addressing an ideal qualitative research process. In the following section, a qualitative research approach will be discussed.

\section{Methodology}

Since this study, which examines the commonly used processes of qualitative research, is carried out by conceptual analysis, certain samples are not included in the text. In addition, this study does not address the frequent mistakes made in qualitative researches and discusses a qualitative research process that is likely to be accepted by the academic community.

\section{Findings}

Qualitative research is a method that interrogates, interprets and tries to understand the problem's natural environment. Qualitative research, which uses qualitative data collection methods such as observation, interview, and text analysis to solve a problem, is a subjective-interpretive process for perceiving previously known or unrecognized problems and realistic handling of natural phenomena related to the problem. Qualitative research is one of the ways in which people develop their knowledge to discover the depths of the social structures and systems that they build with their efforts to understand their potential, solve their secrets and strive. In qualitative research, there is an effort to reach a deep perception of the event or phenomenon examined.

\section{Discussion}

After the qualitative research process has started, there are three important aspects that the researcher should consider. First of all, a detailed theoretical framework should be established which will form the basis of the research and define the research subject. The researcher then develops a systematic, feasible research strategy that is flexible in terms of time and other possibilities. Finally, it should not be forgotten that the research targets a certain audience; the research should be reported consistently in a clear and understandable language that the reader can comprehend.

It focuses on the formation of concepts and theories (inductive) in qualitative research rather than quantitative research based on theory and hypotheses. Unlike quantitative research, qualitative research is directed to subjective data such as people's opinions, experiences, perceptions and emotions and tries to create meaning from the relationships between these data. In addition, qualitative research that depicts a social event in its natural environment and natural formation tries to comprehend the reasons behind the event, not quantitative research that is dependent on experimental processes. Qualitative research seeks answers to abstract questions such as "why, how and in what way en and quantitative research seek answers to concrete questions such as" how much, how much, how often and how widespread yaygin. Qualitative researchers should have the ability to make good observations, to establish moderate relationships with people, to listen effectively and to analyze data well.

In qualitative research, it is aimed to limit the results of the research rather than universal generalizations and to reach generalizations that can be adapted and replicated to different situations. In qualitative research, the events and cases taking place in the social field are the subjects of investigation. 
Due to its dynamic nature, social events may vary according to the situation, time and place. In addition, since qualitative research is a working group in which quantitative research differs significantly from the universe and sampling methods, it is difficult to generalize the research findings to the universe. This is because the working groups of qualitative research are unique and the likelihood that similar ones are found within the social structure. For this reason, only limited and special generalizations can be made in qualitative researches. The framework and limitations of the research should be taken into account when making limited generalizations and these limitations should be detailed in the research report.

\section{Results and Recommendations}

Due to the complex nature of qualitative research and its flexibility to elaborate very different situations, this study aims to introduce this research characteristic. It may be suggested that future studies should address different elements of qualitative research separately. In addition, although there are comprehensive studies in the literature on how dynamic processes in social phenomena should be constructed in qualitative research, this study which deals with a qualitative research process has been carried out to eliminate the conceptual deficiency in the literature. It may be suggested that future researches should be conducted in a manner that includes more examples and in particular leads to investigator errors in the analysis process. Ethical dimensions of qualitative research are not mentioned in this study. Ethical principles and attitudes are important features of the researcher. In this respect, it may be suggested that qualitative research ethics should be included in future studies. 